\title{
Assessment of Weed Management Competency of Field Assistants in Khyber Pakhtunkhwa, Pakistan
}

\author{
Asif Nawaz ${ }^{1 *}$, Muhammad Zafarullah Khan ${ }^{1}$, Rehmat Ullah ${ }^{1}$, Arshad Farooq $^{2}$ and Abdul Hassan ${ }^{2}$
}

${ }^{1}$ Department of Agricultural Extension Education and Communication, The University of Agriculture, Peshawar, Khyber Pakbtunkhwa, Pakistan; ${ }^{2}$ PARC Social Sciences Research Institute, Tarnab, Peshawar, Khyber Pakbtunkhwa, Pakistan.

\begin{abstract}
Weeds can cause significant decrease to the crop yields therefore; it is crucial for the Field Assistants to be competent in providing extension services to the farming community regarding weeds management. Thus, this study was conducted to assess the weeds management competency level of Field Assistants of Khyber Pakhtunkhwa Agriculture Extension Department. Data from 234 randomly selected Field Assistants were collected through pre-tested and validated interview schedule to achieve study objectives. Results showed that highest ranked weeds management competencies at possessed level were familiarity with the names of commonly occurring weeds, ability to identify various types of weeds and aware about indirect weeds control methods. Moreover, it was found that Field Assistants required highest training needs in familiarity with biological weed control followed by critical threshold level of weeds and critical period of weed competition. Findings of Rank Based Quotient revealed that lack of promotion, training opportunities and incentives or motivation were the top most constraints that respondents faced in building the required competencies. Therefore, it is a dire need to provide practical in-service training to the Field Assistants in the identified areas for the adequate acquisition of weeds management competency. Moreover, there is need to minimize the identified constraints so that the Field Assistants could acquire the requisite weed management competency and provide beneficial recommendations to the farming community.

Received | December 15, 2018; Accepted | June 12, 2020; Published | August 06, 2020

*Correspondence | Asif Nawaz, Department of Agricultural Extension Education and Communication, The University of Agriculture, Peshawar, Khyber Pakhtunkhwa, Pakistan; Email: asif.nawaz38300@gmail.com

Citation | Nawaz, A., M.Z. Khan, R. Ullah, A. Farooq and A. Hassan. 2020. Assessment of weed management competency of field assistants in Khyber Pakhtunkhwa, Pakistan. Sarhad Journal of Agriculture, 36(3): 798-805.

DOI | http://dx.doi.org/10.17582/journal.sja/2020/36.3.798.805

Keywords | Biological control, In-service training, Interview schedule, Training needs, Weeds management
\end{abstract}

\section{Introduction}

A gricultural extension can be defined as, "an ongoing process of getting useful information to farmers and assisting them to acquire the knowledge, skills and attitudes to use effectively the information and technology to increase productivity" (Sail, 2010). Agricultural extension workers are the central players in delivering extension services to farmers predominantly in developing nations and needs to possess the required competency in order to facilitate the farming community (Okwoche et al., 2009).
Wisconsin Cooperative Extension (2002) viewed competency as the possession of adequate skills, knowledge and attitudes required by extension agents to effectively discharge their duties. Furthermore, competency is directly associated with extension work, because the ability of extension workers to achieve program objectives depends solely on the quality of skills, knowledge and attitude they possess (Swanson, 2006).

Field Assistants (FA) is considered as the pivot of agriculture extension services. They carry out 
their duties at union council and are qualified diploma holder of three years from Agriculture Services Academy (ASA). They are supervised by Agriculture Officer (AO) at circle level (Ullah et al., 2017). The crucial role of Field Assistant in the dissemination of latest technologies and social and economic development of the nation cannot be overemphasized. Field Assistants educate the farmers to identify their own problems and possible solutions for them by the principle of self-help (Memon et al., 2013). They are providing recommendations to the farming community regarding crop protection, layout demonstration plots and overall farming activities.

Weed can be defined as, plant which is unwanted in a specific location, and its elimination is a cause of social, aesthetic, economic and medical relief for humans. Therefore, weeds are unwanted plants that pervade different crops and cause adverse effect on their produce. Javaid et al. (2007) mentioned the inhibitory effects of weeds on crop plants. Mostly weed-crop competition is complex as weeds compete with the crop plants by occupying a space, which would otherwise be available to the crop plant. Anything that reduces this space reduces the plant growth. Weeds are notorious yield reducers that are, in many situations, economically more important than insects, fungi or other pest organisms that needs to be controlled (Oerke et al., 1994; Savary et al., 1997). Almost $80 \%$ of the worldwide cereal production comes from rice, wheat and maize but these unwanted plants drastically affect their yield (Siddiqui et al., 2010). Rao (2000) reported that in fact the actual reasons of losses caused by various pests are, $20 \%$ from pathogens, 30\% from insects whereas $45 \%$ loses from different type of toxic weeds infestation due to which sample farmers fail to identify and control these weeds in right stage and time.

Khan et al. (2009) suggested that Agriculture Officers need trainings to develop their competency regarding problems of weeds. Similarly, Chahal et al. (2015) highlighted that Para Extension Workers (PEWs) have insufficient knowledge in weed management. Also, Khan et al. (2012) were of the view that farmers can manage/ control weeds provided that extension agents are proficient and competent to educate farmers about weeds management. Since bulk of the farming community in Pakistan and especially in Khyber Pakhtunkhwa are uneducated along with least access to newspapers, research articles and other agriculture related magazines, therefore, they are totally dependent on the agriculture extension agents. Therefore, keeping in view the significance of weeds management in crop production, this study was designed with the objectives to find required and possessed level of weeds management competency of the Field Assistants, their training needs along with constraints impeding acquisition of weed management competency.

\section{Materials and Methods}

\section{Study area}

This study was conducted in Khyber Pakhtunkhwa province and all the Field Assistants working in Khyber Pakhtunkhwa Department of Agriculture Extension constituted the population of the study.

\section{Selection of sample}

The provincial Directorate General of Agriculture Extension was contacted to know about total number of Field Assistants staff in the province. According to the directorate records, there were 543 Field Assistants offering their services in the province (DGAE, 2018). An appropriate sampling procedure was used for the selection of suitable sample size due to vast area and also due to financial expenses incurred on data collection of the entire province. Hence, a sample size of 234 Field Assistants was selected for the present study by using Sekaran (2006) sampling technique due to known population of Field Assistants. Khyber Pakhtunkhwa is divided into four agro-ecological zones such as Central Plain Valley, Southern Piedmont Plain, Eastern Mountainous Zone and Northern Mountainous Zone (Khyber Pakhtunkhwa Climate Change Policy, 2016). Therefore, proportional allocation sampling technique was used for the distribution of the respondents regarding agro-ecological zones of the Khyber Pakhtunkhwa province; also used by Ali et al. (2013) and Sajjad et al. (2012). Hence, 88 Field Assistants were selected from central plain valley, 55 from southern piedmont plain, 42 from eastern mountainous zone and 49 from northern mountainous zone.

\section{Data collection}

Field Assistants were personally interviewed through a well-structured and pre-tested interview schedule designed for them in the light of study objectives based on literature review and agricultural expert consultation. The respondents were interviewed to rate each competency statements relative to their 
perception of the possessed and required level using a five point likert scale. The weight assigned to each number were; 1 for very low, 2 for low, 3 for medium, 4 for high and 5 for very high, which was chosen because it provides greater flexibility and is also simple to construct. Interview schedule was pre-tested on 20 Field Assistants prior to data collection in order to rectify any inadequacies and reduce biasness. Cronbach's Alpha test was calculated to check the reliability of the interview schedule by using Statistical Package for Social Sciences (SPSS) software that was 0.896 which shows to be good internal consistency. Mean rating values for each competency statement was computed and used to indicate respondents' level of competence. The scheme used by Villarreal (2003) was used to interpret the mean values of competency statements which indicate respondents' level of competency as follows:

0.00-1.49 = Not competent (Very low competency)

1.50-2.49 = Less than average (Low competency) 2.50-3.49 = Average Competence (Medium Competency) 3.50-4.49= Above average competence (High competency) 4.50-5.00 = Very competent (Very bighly competent)

\section{Data analysis}

Data was analyzed by using Statistical Package for Social Sciences (SPSS) V.20 and descriptive statistics were utilized for presentation of the results. Paired sample t-test was applied to check the significant difference between means of the possessed and required levels of their weeds management competency. The pair $\mathrm{t}$-test for convenience is given as:

$$
t=\frac{\bar{d}}{S d \sqrt{n}}
$$

Where;

$\mathrm{d}=$ difference between two sample observations (Possessed and Required Level); n= number of pairs; $\mathrm{Sd}=$ standard deviation.

$$
\mathrm{Sd}=\sqrt{\frac{\sum\left(d_{i}-\bar{d}\right)^{2}}{n-1}} \text { and } \bar{d}=\frac{\sum d_{i}}{n} \text {, the meaqn of } d-\text { values }
$$

The major constraints impeding acquisition of required weed management competency were listed and Rank Based Quotient (RBQ) of constraints was calculated based on the ranking done by 234 respondents. Rank Based Quotient was calculated using following formula given by Sabarathnam (1988):

$$
R B Q=\frac{\sum f_{i}(n+1-i) \times 100}{N \times n}
$$

Where;

$\mathrm{i}=$ Concerned rank of the constraint; $n=$ Number of ranks; = Number of Respondents; $\mathrm{f}_{\mathrm{i}}=$ Frequency of respondents mentioning the $\mathrm{i}^{\text {th }}$ rank.

\section{Results and Discussion}

\section{Required and possessed level of weeds management competencies}

Data regarding required and possessed level of weeds management competencies in Table 1 reveals that overall mean competency possessed by field assistants regarding weeds were 3.86 against the required level of 4.31. Familiarity with names of commonly occurring weeds was ranked at $1^{\text {st }}$ order on possessed level with mean value of 4.62 and required mean value of 4.67. Since Field Assistants are performing their duties by interacting with the farming community and also visits their fields which make them familiar with names of the commonly occurring weeds. Ability to identify various types of weeds was ranked at $2^{\text {nd }}$ order on possessed level with mean value of 4.48 and required mean value of 4.65 . This is due to the fact that every area has certain specific weeds and as the Field Assistant working in that area, the farmers of that respective area report them about major weeds of that area in order to control them and therefore they were competent enough in identification of weeds.

The third ranked competencies at possessed level was awareness about indirect methods of weed control with mean possessed level of 4.47 while required level was 4.54. Use of clean seeds, clean farm equipments, clean watercourses and canals, control grazing of livestock and use of farm yard manure and other soil materials were the prominent indirect weed control methods pointed by the respondents that they recommend to the farming community. Competency in understanding proper time of weedicide application stood at $4^{\text {th }}$ order on possessed level with mean value of 4.32 and 4.40 for required level. Knowledge of numerous weedicide was on $5^{\text {th }}$ rank of possessed level (mean=4.22), followed by ability to calculate amount of weedicide needed with mean value of 4.21 against the required mean value of 4.33 . This showed that Field Assistants were competent in use of weedicides i.e., proper time of weedicide application, familiarity with numerous weedicides and amount of weedicide 
needed. During informal discussion with the respondents, they revealed that farming community mostly preferred weedicides application comparison to other techniques; that's why they themselves had enough bred to be competent for serving the farming community.

Competencies in knowledge about fallowing techniques to minimize weeds, familiarity with cultural weed control and knowledge about integrated weed management was ranked $7^{\text {th }}, 8^{\text {th }}$ and $9^{\text {th }}$ order of possessed level with mean value of $4.19,3.85$ and 3.47 against the required level of $4.28,4.23$, and 4.05 respectively. Knowhow about herbicide formulations stood at $10^{\text {th }}$ rank on possessed level with mean value of 3.39 while mean required value was 4.10 . The three lowest ranked competencies on possessed level were; familiarity with biological control of weed control $($ mean $=2.56)$ familiarity with critical threshold level of weeds (mean=3.08) and familiarity with critical period of weed competition (mean=3.32).

Biological control methods involve the control of weeds by using insects, pathogens, and certain birds and fish against weeds. It is considered one of the best methods for weed control due to its effectiveness and environmental safety. However, biological weed control techniques are the most difficult to develop and practice because it takes long time to identify a selective natural enemy and arrive at a specific degree of precision to control specific weed species. Therefore, this method is not practiced among the farming community and also they were not provided training on this aspect which result that they are not competent in this competency. The mean of possessed level of weed competencies was 3.86 while mean of the overall required level of weed competencies was 4.31 which showed that Field Assistant had better weed management competency. Somewhat similar results were reported in Khyber Pakhtunkhwa by Khan et al. (2012) who concluded that majority of the Agriculture Officers were incompetent to describe weeds of major and minor crops and their impact on crop production and also to properly guide farmers about herbicide application.

\section{Training needs in weeds management competencies}

Table 2 depicts the training needs of Field Assistants based on the mean difference between the possessed and required level regarding weeds management competency. Results shows that familiarity with biological weed control techniques was at top most rank of training needs with mean difference of -1.41 and $t$-value of -21.35 and had highly significant $(\mathrm{P} \leq 0.01)$ mean difference between the possessed and required level. Competency of Field Assistants in familiarity with critical threshold level of weeds was at $2^{\text {nd }}$ rank of training need with mean difference of -1.05 and $t$-value of -17.38 with highly significant $(\mathrm{P} \leq 0.01)$ mean difference between possessed and required level. Third ranked training need was reported in the competency of familiarity with critical period of competition of weeds with highly significant mean difference $(\mathrm{P} \leq 0.01)$ between the possessed and required level (mean difference $=-0.86$, $\mathrm{t}$-value $=-15.46)$.

Training needs in competencies of knowhow about herbicide formulations, knowledge about integrated weed management and familiarity with cultural weed control was ranked at $4^{\text {th }}, 5^{\text {th }}$ and $6^{\text {th }}$ order with mean difference of $-0.71,-0.58,-0.38$ and $t$-values of $-12.14,-10.44$ and -8.49 respectively. Competencies in knowledge about numerous weedicides for weed control as training need was ranked at $7^{\text {th }}$ order with mean difference of -0.25 and $t$-value of -6.11 . Results of paired T-test showed that there was highly significant mean difference $(\mathrm{P} \leq 0.01)$ between mean possessed and required level of competencies in know how about herbicide formulations, knowledge about integrated weed management, familiarity with cultural weed control and knowledge about numerous weedicides for weed control.

Highly significant $(\mathrm{P} \leq 0.01)$ difference between the mean possessed and required level was reported in identifying various types of weeds with a mean difference of -0.16 and t-value of-2.96.Non-significant difference was reported at 1\% level of probability in mean possessed and required level of competencies in ability to calculate the amount of weedicide needed, knowledge about fallowing techniques to minimize weeds, understanding proper time of weedicide application, awareness about indirect methods of weed control, and familiarity with names of commonly occurring weeds and ranked at $9^{\text {th }}, 10^{\text {th }}, 11^{\text {th }}, 12^{\text {th }}$ and $13^{\text {th }}$ order of training needs. These results indicated that Field Assistants did not needed trainings in chemical weed control methods but they need training in other weeds control methods along with herbicide formulations and integrated weed management. These results are partially in line with those of 
Table 1: Mean, SD and rank of the required and possessed level of weeds management competencies.

\section{Sr. \# Competencies statements}

1. Familiarity with names of commonly occurring weeds

2. Ability to identify various types of weeds

3. Aware about indirect methods of weed control

4. Knowledge of numerous weedicides

5. Understand proper time of weedicidesapplication

6. Ability to calculate the amount of weedicide needed

7. Knowledge about fallowing techniques to minimize weed infestation

8. Familiarity with cultural weed control

9. Familiarity with critical period of competition of weeds

10. Familiaritywith critical threshold level of weeds

11. Knowhow about herbicide formulations

12. Knowledge about integrated weed management

13. Familiaritywith biological weed control techniques

Overall Mean
Required level Possessed level

Mean SD Rank Mean SD Rank

$\begin{array}{llllll}4.67 & 0.57 & 1 & 4.62 & 0.66 & 1\end{array}$

$\begin{array}{llllll}4.65 & 0.48 & 2 & 4.48 & 0.78 & 2\end{array}$

$\begin{array}{llllll}4.54 & 0.68 & 3 & 4.47 & 0.77 & 3\end{array}$

$\begin{array}{llllll}4.47 & 0.73 & 4 & 4.22 & 0.86 & 5\end{array}$

$\begin{array}{llllll}4.40 & 0.74 & 5 & 4.32 & 0.87 & 4\end{array}$

$\begin{array}{llllll}4.33 & 0.77 & 6 & 4.21 & 0.87 & 6\end{array}$

$\begin{array}{llllll}4.28 & 0.83 & 7 & 4.19 & 0.85 & 7\end{array}$

$\begin{array}{llllll}4.23 & 0.77 & 8 & 3.85 & 0.88 & 8\end{array}$

$\begin{array}{llllll}4.18 & 0.77 & 9 & 3.32 & 0.65 & 11\end{array}$

$\begin{array}{llllll}4.13 & 0.82 & 10 & 3.08 & 0.55 & 12\end{array}$

$\begin{array}{llllll}4.10 & 0.80 & 11 & 3.39 & 0.61 & 10\end{array}$

$\begin{array}{llllll}4.05 & 0.84 & 12 & 3.47 & 0.72 & 9\end{array}$

$\begin{array}{llllll}3.97 & 0.89 & 13 & 2.56 & 0.81 & 13\end{array}$

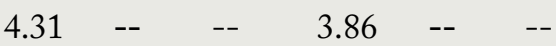

Source: Field Survey, 2017.

Table 2: Rank order of training needs based on mean required and possessed level of weeds management competencies.

\section{Sr. Competencies statements}

1. Familiarity with biological weed control techniques

2. Familiarity with critical threshold level of weeds

3. Familiarity with critical period of competition of weeds

4. Knowhow about herbicide formulations

5. Knowledge about integrated weed management

6. Familiarity with cultural weed control

7. Knowledge of numerous weedicides

8. Ability to identify various types of weeds

9. Ability to calculate the amount of weedicides needed

10. Knowledge about fallowing techniques to minimize weed infestation

11. Understand proper time of weedicide application

12. Aware about indirect methods of weed control

13. Familiarity with names of commonly occurring weeds

$\begin{array}{lllll}\begin{array}{l}\text { Possessed Required Training need/ } \\ \text { level }\end{array} & \text { Rank t-value } \\ 2.56 & 3.97 & -1.41 & 1 & -21.35^{* *} \\ 3.08 & 4.13 & -1.05 & 2 & -17.38^{* * *} \\ 3.32 & 4.18 & -0.86 & 3 & -15.46^{* *} \\ 3.39 & 4.10 & -0.71 & 4 & -12.14^{* *} \\ 3.47 & 4.05 & -0.58 & 5 & -10.44^{* *} \\ 3.85 & 4.23 & -0.38 & 6 & -8.49^{* *} \\ 4.22 & 4.47 & -0.25 & 7 & -6.11^{* *} \\ 4.48 & 4.65 & -0.16 & 8 & -2.96^{* *} \\ 4.21 & 4.33 & -0.12 & 9 & -1.78^{\mathrm{NS}} \\ 4.19 & 4.28 & -0.09 & 10 & -1.58^{\mathrm{NS}} \\ 4.32 & 4.40 & -0.08 & 11 & -1.23^{\mathrm{NS}} \\ 4.47 & 4.54 & -0.07 & 12 & -1.02^{\mathrm{NS}} \\ 4.62 & 4.67 & -0.06 & 13 & -1.22^{\mathrm{NS}}\end{array}$

NS: represents Non Significant whereas" represents significance at 1\% level of probability. Source: Field survey, 2017.

Khan (2017) who reported that Agriculture Officers of Khyber Pakhtunkhwa ranked training needs regarding farmers' guidance about herbicides use for weed, describe the control measures of insect/pest and identify the weeds of major field crops at lowest ranked order.

\section{Constraints faced in building the needed competencies}

The rate of competency acquisition among the Field Assistants is significantly governed by the constraints faced during their job. Therefore, commonly cited constraints preventing acquisition of core competencies were listed and the sampled Field Assistants were asked to rank them. Rank Based Quotient (RBQ) was applied on the ranks identified for each constraint by respondents and results were analyzed and presented in Table 3. Results in Table 3 shows that lack of promotion/Upgradation stood at $1^{\text {st }}$ rank $(\mathrm{RBQ}=91.7 \%)$ followed by lack of training opportunities with RBQ of $87.9 \%$ and lack of incentives or motivation at $3^{\text {rd }} \operatorname{rank}(\mathrm{RBQ}=83.2 \%)$. The respondents revealed during informal discussion that no proper promotion structure exists for the Field Assistants staff which is a dilemma and mostly 
Table 3: Constraints faced in building needed competencies.

$\begin{array}{llllllllllllll}\text { Constraints } & \text { Rank } & & & & & & & & & & & \text { RBQ } & \text { RO } \\ & \mathbf{1} & \mathbf{2} & \mathbf{3} & \mathbf{4} & \mathbf{5} & \mathbf{6} & \mathbf{7} & \mathbf{8} & \mathbf{9} & \mathbf{1 0} & \mathbf{1 1} & \mathbf{( \% )} \\ \text { Lack of Promotion/Upgradation } & 146 & 21 & 35 & 13 & 11 & 8 & - & - & - & - & - & 91.7 & \text { I } \\ \text { Lack of Training opportunities } & 122 & 21 & 44 & - & 37 & 6 & 4 & - & - & - & - & 87.9 & \text { II } \\ \text { Lack of Incentives/Motivation } & 98 & 43 & - & 18 & 40 & 35 & - & - & - & - & - & 83.2 & \text { III } \\ \text { Poor Coordination among Line Departments } & 41 & 36 & 20 & 26 & 57 & 8 & 15 & 12 & - & 19 & - & 70.2 & \text { IV } \\ \text { Lack of Organizational Support } & 35 & 47 & 17 & 26 & 38 & 13 & 28 & - & 9 & 21 & - & 68.7 & \text { V } \\ \text { Poor Skills on the use of ICTs facilities } & 54 & 47 & 13 & 7 & 37 & 21 & - & - & - & 17 & 38 & 65.8 & \text { VI } \\ \text { Lack of needed Facilities } & 31 & 55 & - & - & 22 & 47 & - & - & - & 79 & - & 57.6 & \text { VII } \\ \text { Lack of Incentives for Higher Education } & 14 & 49 & 25 & - & 72 & - & - & - & - & 14 & 60 & 56.8 & \text { VIII } \\ \text { Greater Area under Control } & 26 & 53 & 5 & 8 & 11 & 18 & 15 & 9 & 31 & 16 & 42 & 53.9 & \text { IX } \\ \text { Lack of Credible Information } & - & - & 23 & - & 35 & - & - & - & - & 61 & 115 & 26.8 & \text { X } \\ \text { Lack of Personal Interest } & - & - & - & - & - & - & - & 23 & 19 & 38 & 154 & 14.7 & \text { XI }\end{array}$

Source: Field Survey, 2017.

the staff is dishearten due to which they do not utilize their efforts for increasing their competencies. Provision of training to the Field Assistant staff is essential in order to increase their knowledge and skills regarding improved farming practices but in the absence of training opportunities they are not familiar with the latest innovations and hence they cannot provide unique and innovative ideas to the farming community. Lack of incentives for building the required competencies has significant effect towards acquisition of core competencies by the Field Assistants staff because incentives acts the role of extrinsic motivation and they are motivated to acquire new and needed competencies.

The result in Table 3 also reveals that poor coordination among the line department was at $4^{\text {th }}$ rank order with RBQ of $70.2 \%$. Effective coordination among the line department of agriculture has greater role in competencies development because when these Field Assistants interacts with these departments resultantly increase their competency by sharing information regarding farmer's problem and improved farming practices. The results also showed that fifth ranked constraint was lack of organizational support $(\mathrm{RBQ}=68.7 \%)$, sixth ranked was poor skills on use of ICTs facilities (RBQ $=65.8 \%)$, seventh ranked was lack of needed facilities $(\mathrm{RBQ}=57.6 \%)$ and lack of incentives for higher education $(\mathrm{RBQ}=56.8 \%)$ was reported at rank $8^{\text {th }}$.

The respondents argued that lack of organizational support in building the required competencies not only restricts them from acquiring new knowledge and skills but also reduces their individual importance in the organization. It was found during an interaction with the respondents that majority of the respondents does not possess skills regarding use of ICTs facilities; therefore, they cannot utilize the information sources which contribute significantly towards their competencies development. Respondents revealed about lack of needed facilities that they should provide a properly established office in the area of jurisdiction and also transport facilities so that they can interact with farming community easily. The respondents further highlighted that department had no proper incentives for acquiring higher education and this was also the reason that majority of the sampled Field Assistants had only basic education.

The results further showed that $9^{\text {th }}$ and $10^{\text {th }}$ ranked constraints had greater area under control and lack of credible information with RBQ of $53.9 \%$ and $26.8 \%$ respectively. The respondents highlighted that due to greater area under jurisdiction and overabundance of other related responsibilities, they do not concentrate on building the competencies needed for them. The respondents argued regarding lack of credible information that also there is lack of information according to their conditions in local areas in which they are offering services. Lack of personal interest for developing the required competencies was ranked at $11^{\text {th }}$ order with RBQ of $14.7 \%$. Mostly old aged respondents showed a higher response towards lack of personal interest whereas the young Field Assistants were enthusiastic to acquire new competencies. These results are somewhat similar to those of Lakai et al. (2012) who identified that increase workload, lack of 
time and funding, and increased personal costs for acquiring competencies were top most barriers for acquisition of extension competencies while lack of personal motivation and credible information were the least affecting barriers. Shinn and Smith (1999) in Texas reported that time pressure, increase workload, personal costs in acquiring needed competencies, lack of local funds and lack of monetary awards were key barriers that discouraged the extension agents from acquiring core competencies. Knowles et al. (2005) indicated that adult learners are more attracted towards extrinsic motivators that include possibility of higher salaries, promotion and better jobs. Harder et al. (2010) highlighted barriers such as financial costs, lack of job commitment and limited time were preventing extension agents to develop cross-cultural competencies. Shinn and Smith (1999) reported that peer recognition; performance based salary and promotion, personal satisfaction, respect from clients, and financial benefits were the five foremost rewards that encouraged extension agents to acquire core competencies.

\section{Conclusions and Recommendations}

It can be concluded from the instant study that Field Assistants were competent and does not required training in familiarity with names of commonly occurring weeds, indirect methods of weed control, understanding proper time of weedicide application, fallowing techniques to minimize weed infestation and calculating amount of weedicides. However, Field Assistant were incompetent in biological weed control techniques, familiarity with threshold level of weeds, critical period of competition of weeds, herbicide formulation, integrated weed management. The findings also concluded that lack of promotion; incentives and poor coordination among line department of agriculture were constraints that considerably affected the development of required competency of the Field Assistants. There is a dire need to provide practical in-service training for the Field Assistants in the identified areas for the adequate acquisition of weeds management competency. Moreover, there is need to minimize the identified constraints so that the Field Assistants could acquire requisite weed management competency and provide beneficial recommendations to the farming community.

\section{Novelty Statement}

The present study highlighted essential training needs of the Field Assistants which is needed for them for their effective job performance. The identified competencies if acquired by field assistants will help them to assist farming community of the province regarding weed management.

\section{Author's Contribution}

Asif Nawaz conducted this study, reviewed literature and wrote introduction. Muhammad Zafarullah Khan developed main idea of the research. Rehmat Ullah assisted in data collection, data analysis and composed conclusions and recommendations. Arshad Farooq provided guidance in writing abstract and results and discussion section. Abdul Hassan assisted in writing materials and methods, corrected references and proofread the article.

\section{Conflict of interest}

The authors have declared no conflict of interest.

\section{References}

Ali, M.S., M.F. Karim, A.K. Azad and S.V.R.K. Prabhakar. 2013. Training modules for climate change adaptation in agriculture: sub-district and district level. Agric. Off. Bangladesh. Hayama, Japan: IGES. pp. 19.

Chahal, V.P., D.S. Yadav, S.K. Thakur and P. Sood. 2015. Assessing knowledge gaps of para extension workers for improving their capacity in dissemination of farm technology to farmers in Mandi district of Himachal Pradesh, India. Indian J. Agric. Sci. 85(2): 229-233.

Directorate General of Agriculture Extension. 2018. Report for workshop on "Roles and Responsibilities of Agricultural Inspectors and Supervisors" in District Mardan. As Annexure-F-1. No. 16/115/Estt/8812-36/ DG-Peshawar on Dated: $18^{\text {th }}$ May, 2017.

Harder, A., A. Lamm and P. Vergot. 2010. Explore your world: Professional development in an international context. J. Ext. [On-line], 48(2), 2FEA3. Retrieved from: http://www.joe.org/ joe/2010april/a3.php. Accessed On: 17th June, 2018.

Javaid, A., R. Bajwa, N. Rabbani and T. Anjum. 2007. Comparative tolerance of six rice (Oryza sativa L.) genotypes to allelopathy of purple nutsedge (Cyperusrotundus L.). Allelopathy J. 20(1): 157-166.

Khan, M.Z., 2017. Assessment of extension agents' knowledge and skills regarding pest management 
in Khyber Pakhtunkhwa Province-Pakistan. AGROFOR Int. J. 2(2): 132-141. https://doi. org/10.7251/AGRENG1702132K

Khan, M.Z., J. Ullah, S. Ahmad and M. Qasim. 2012. Assessing professional capabilities of Agriculture Officers for weed control: A case study of Khyber Pakhtunkhwa, Pakistan. Pak. J. Weed Sci. Res. 18(1): 79-90.

Khan, M.Z., S. Pongqan and J. Ullah. 2009. An analysis of professional competencies of Agriculture Officers to cope with problem of weeds in North West Frontier Province, Pakistan. J. Agric. Ext. Rural Dev. 1(2): 58-62.

Khyber Pakhtunkhwa Climate Change Policy. 2016. Final draft of Khyber Pakhtunkhwa climate change policy (2016) published by environmental protection agency government of Khyber Pakhtunkhwa For. Environ. Wildl. Dept.pp. 4.

Knowles, M.S., E.F. Holton and R.A. Swanson. 2005. The adult learner: The definitive classic in adult education and human resource development (6 ${ }^{\text {th }}$ Ed.). San Diego, CA: Elsevier. pp. 56.

Lakai, D., K.S.U. Jayaratne, G.E. Moore and M.J. Kistler. 2012. Barriers and effective educational strategies to develop extension agents' professional competencies. J. Ext., 50(4): Available Online at: https://www.joe. org/joe/2012 august/pdf/JOE_v50_4rb1.pdf. Accessed On: 29 ${ }^{\text {th }}$ Sept, 2017.

Memon, R.A., E. Bashir, H.U.R. Mian and A.R. Nasimullah. 2013. Extension methods. Natl. Book Found., Pakistan. pp. 54-56.

Oerke, E.C., H.W. Dehne, F. Schönbeck and A. Weber. 1994. Crop production and crop protection: estimated losses in major food and cash crops. Elsevier, Amsterdam. pp. 44.

Okwoche, V.A., E.P. Ejembi and C.P.O. Obinne. 2009. A comparative analysis of competencies needed by female and male village agricultural extension agents in Benue State, Nigeria. Prod. Agric. Technol. J., (PAT). 5(2): 278-287.

Rao, V.S., 2000. Principles of weed science. Second edition. Science publisher, Inc., NH, USA. pp. 1-2. https://doi.org/10.1201/9781482279603

Sabarathnam, V.E.,1988.Manual of field experience training for ARS scientists, NAARM, Hyderabad. pp. 30.

Sail, R.M., 2010. Empowering of agricultural extensionists: A case study of frontline extensionists of one agricultural extension agency. Int. Conf. Agric. Ext., (AGREX'10): Empowering of agri-food stakeholders in facing global challenges towards sustainability, 26-28 Oct. 2010, Palm Garden Hotel, IOI Resort Putrajaya, Malaysia. pp. 1166-1199.

Sajjad, M., M. Khan, M. Zulfiqar, S. Ali, M. Nazir and A. Ali. 2012. Technical efficiency analysis of milk production in Khyber Pakhtunkhwa province: A stochastic frontier approach. Pak. J. Life Soc. Sci. 11(4): 36-41.

Savary, S., R.K. Srivastava, H.M. Singh and F.A. Elazegui. 1997. A characterization of rice pests and quantification of yield losses in the rice-wheat system of India. Crop Protect. 16: 387-398. https://doi.org/10.1016/S02612194(96)00108-1

Sekaran, U., 2006. Research methods for bussiness. USA, Harnitage Publ. Ser. pp. 468.

Shinn, G. and K. Smith. 1999. Anticipating roles of the cooperative extension service in 2010: A delphi technique involving agricultural and natural resource agents and family and consumer science agents in Texas. Proc. $26^{\text {th }}$ Annu. Natl. Agric. Educ. Res. Conf., Florida. pp. 109-116.

Siddiqui, I., R. Bajwa, Zil-e-Huma and A. Javaid. 2010. Effect of six problematic weeds on growth and yield of wheat. Pak. J. Bot. 42(4): 2461-2471.

Swanson, B.J., 2006. Impact of natural and artificial barriers to dispersal on the population structure of bobcats. J. Wildl. Manage. 71(1): 96-102. https://doi.org/10.2193/2005-563

Ullah, R., K. Ullah, I. Ullah, M.Z. Khan and A. Nawaz. 2017. Field assistants impact on agricultural extension activities: A case study of district Dera Ismail Khan, Khyber Pakhtunkhwa-Pakistan. Pak. J. Agric. Res. 30(3): 287-293. https://doi.org/10.17582/ journal.pjar/2017.30.3.287.293

Villarreal, N., 2003. Analysis of computer knowledge, skills and experience of students enrolled in undergraduate courses in the college of agricultural sciences and natural resources. Texas: Texas Tech Univ. pp. 28.

Wisconsin Cooperative Extension. 2002. Competencies for extension faculty and academic staff in community based educator roles. Wisconsin: Univ. Wisconsin Publ. pp. 34. 